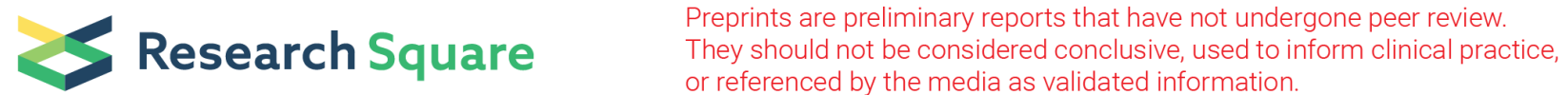

\section{Application of WASP Model to Simulate Water Pollution Control of Duriangkang Dam}

Calvin Wimordi ( $\nabla$ calvinwimordi@gmail.com )

Universitas Katolik Parahyangan https://orcid.org/0000-0001-7657-0200

Doddi Yudianto

Universitas Katolik Parahyangan

Yiqing Guan

Hohai University

Research

Keywords: Duriangkang Dam, water pollution control, WASP model, Batam City

Posted Date: June 2nd, 2020

DOI: https://doi.org/10.21203/rs.3.rs-30306/v1

License: (1) This work is licensed under a Creative Commons Attribution 4.0 International License.

Read Full License 


\section{Abstract}

Located in Batam City, Duriangkang Dam plays an important role in the area's clean water provision regarding the fact that it is the first and largest estuary dam in Indonesia. However, with its total effective volume of $107,000,000 \mathrm{~m} 3$, Duriangkang Dam is now heavily polluted due to the enormous wastewater, both domestic and industrial, that are directly discharged into the dam. Moreover, the practice of fish farming has also contributed in making it worse. From the water sampling taken from 2016 to 2018, the water condition in Duriangkang Dam is no longer classified as the 2 nd class of raw water standard in Indonesia. This study employs the WASP model to evaluate and simulate the possible solution to control the water pollution rate in Duriangkang Dam. The water quality indicators, namely dissolved Oxygen (DO), total phosphorus (TP), and biochemical oxygen demand (BOD) will be modeled in this study. The calibration and verification results indicate the model shows excellent fitting for DO and TP but slightly less for BOD. Under several scenarios, it is identified that the best way to control the pollution rate within the dam is by implementing scenario 8 that totally eliminates the fish farm and domestic wastewater load.

\section{Introduction}

Water is one of the most important elements to support human life and only 35 million $\mathrm{km}^{3}$ being available as consumed water (freshwater) and among it, due to several factors such as easily accessible, the surface water becomes one of the main freshwater sources that is used in many countries in the world. However, in addition to the easily accessible advantages, surface water also has disadvantages such as easily contaminated. The surface water is most vulnerable to be polluted due to its easy accessibility for the disposal of wastewater. Both the natural processes, such as precipitation inputs, erosion, weather of crustal materials, as well as the anthropogenic influences viz. urban, industrial and agricultural activities, increasing exploitation of water resources, together determine the quality of surface in a region (Carpenter et al.., 1998; Jarvie et al.,, 1998).

Duriangkang Dam, the first and largest estuary dam in Indonesia, plays an important role to supply clean water for Batam City since it was initially operated in 1995. Recent study in 2015 showed that the Duriangkang Dam was suffering from high sedimentation and water pollution. Based on the water quality monitoring data, the concentration of DO, BOD, and TP were found exceeding the maximum allowable concentration of raw water in Indonesia. To understand better the situation, water quality modeling becomes necessary to control and restore the water as its designated use of Class II.

According to Blacerzak (2006), Water Quality Analysis Simulation Program (WASP) is one of the most used programs to solve a broad range of problems connected with water quality. Besides that, the WASP is also able to estimate and simulate the eutrophication occurrence. The selection of WASP to be used rather than other software model is because the flexibility afforded by the WASP is unique and it allows the user to investigate one, two, and three-dimensional systems, allows the specification of time-variable exchange coefficients, advective flows, variety of pollutant types and water quality boundary conditions; 
permit tailored structuring of the kinetic processes, all within the larger modeling framework without having to write or rewrite large sections of computer code. Therefore, WASP will be used to model the Duriangkang Dam and as a tool to restore the water quality by applying several pollution control scenarios.

\section{Materials And Methods}

\section{Description of Study area}

Duriangkang Dam is located in Bagan Village, Seibeduk Sub-district, Batam City, Riau Island Province. Geographically, Duriangkang Dam is located at $01^{\square} 02^{\prime} 24^{\prime \prime} \mathrm{N}$ and $104^{\square} 05^{\prime} 11^{\prime \prime}$ E. Duriangkang Dam supply clean water for Batam City for about $3.0 \mathrm{~m}^{3} / \mathrm{s}$. Based on the Inspection and Safety Evaluation Report of Duriangkang Dam, it is known that the area of reservoir inundation area at elevation $+7.5 \mathrm{~m}$ is $24.6 \mathrm{~km}^{2}$.

Recent study in 2015 showed that the total effective volume has significantly decreased for about $25,000.000 \mathrm{~m}^{3}$. In addition, Duriangkang Dam is also identified to be severely polluted by domestics and industrial wastewater. This situation is exacerbated by the existence of fish farms and the water hyacinths are found and cover $180 \mathrm{Ha}$ of the dam area. As a source of clean water, the dam water annually is sampled and tested. The data set for this study based on water sampling in 2016, 2017, and 2018. The survey was taken under a cloudy condition whereas the recorded water level was $+6.30 \mathrm{~m}$ and the sampling was taken at depth of $2 \mathrm{~m}$. The sampling location and results for DO, BOD, and TP can be seen in Figure 1 and Table 1 respectively. From Table 1, it can be seen that the water quality in the dam is improving annually especially for DO concentrations but for TP and especially BOD, the value still does not meet the water standard. In 2016, the water quality was relatively poor due to the dry seasons that started from 2014 to 2016. Based on the test results, this study is expected to promote appropriate solution to restore water quality of Duriangkang Dam. 


\begin{tabular}{|c|c|c|c|c|c|c|c|c|c|}
\hline \multirow[t]{3}{*}{ Location } & \multicolumn{3}{|c|}{2016} & \multicolumn{3}{|c|}{2017} & \multicolumn{3}{|c|}{2018} \\
\hline & DO & TP & BOD & DO & TP & BOD & DO & TP & BOD \\
\hline & \multicolumn{9}{|c|}{$(\mathrm{mg} / \mathrm{L})$} \\
\hline 1 & 3.3 & 11.8 & 26 & 6.4 & 1.9 & 10 & 7.2 & $<0.1$ & 4.7 \\
\hline 2 & 3.0 & 16.4 & 39 & 5.0 & 1.3 & 38 & 6.1 & $<0.1$ & 4.2 \\
\hline 3 & 3.2 & 13.9 & 26 & 6.3 & 1.6 & 11 & 5.3 & $<0.1$ & 12.4 \\
\hline 4 & 3.3 & 9.0 & 27 & 6.6 & $<0.1$ & 10 & 6.5 & $<0.1$ & 4.5 \\
\hline 5 & 3.2 & 12.1 & 28 & 6.0 & 1.2 & 11 & 6.0 & 0.1 & 7.5 \\
\hline 6 & 3.5 & 11.7 & 32 & 6.1 & 1.2 & 12 & 5.4 & 0.2 & 8.4 \\
\hline 7 & 3.3 & 10.7 & 27 & 6.2 & 1.2 & 11 & 5.6 & 0.2 & 7.2 \\
\hline 8 & 3.0 & 17.6 & 30 & 6.3 & 1.8 & 10 & 5.7 & 0.2 & 12.3 \\
\hline
\end{tabular}

Table 1

Sampling test results for each location

The Duriangkang Dam receives inflows from upper rivers and outflow of Muka Kuning Dam. Because there is no specific measurement on the river discharge, the inflow data is converted based on the daily water level within the Duriangkang Dam. While limited outflow discharge and water quality data are available for Muka Kuning. The water quality data for Muka Kuning Dam is available only for year of 2015. Due to limited data available, the outflow water quality of Muka Kuning will be applied for further modeling in 2016-2018. While the water quality of incoming rivers to Duriangkang Dam will be assumed following the water quality measured at the reservoir inlets. Besides that, other data such as rainfall, wind speed, water temperature, and solar radiation are also required in this study. Precipitation data is obtained from the rainfall station in Hang Nadim Airport, Batam City, the wind speed, and water temperature data is obtained from Meteorology, Climatology, and Geophysical Agency of Indonesia as for solar radiation data retrieved from NASA's POWER Data Access View.

\section{Water Quality Analysis Simulation Program (WASP)}

Water Quality Analysis Simulation Program or known as WASP is a software developed by US EPA (United States Environmental Protection Agency) and it is public domain software. WASP is an enhancement of the original WASP (Di Toro et al.,, 1983; Connolly and Winfield, 1984; Ambrose, R. B. et al., 1988). This model helps users interpret and predict water quality response to natural phenomena and manmade pollution for various management decisions. WASP is a dynamic compartment-modeling program for the aquatic system, including both the water column and the underlying benthos. The timevarying processes of advection, dispersion, point and diffuse mass loading, and boundary exchange are represented in the basic program (Wool, T., et al, 2001). The flexibility afforded by the WASP is unique. 
WASP allows the user to investigate one, two, and three-dimensional systems, allows the specification of time-variable exchange coefficients, advective flows, variety of pollutant types and water quality boundary conditions; permit tailored structuring of the kinetic processes, all within the larger modeling framework without having to write or rewrite large sections of computer code. WASP also can be linked with a hydrodynamic and sediment transport model that can provide flows, depths velocities, temperature, salinity and sediment fluxes.

According to Wool, et al (2001), WASP comes with two sub-programs, TOXI for toxicant and EUTRO for conventional water quality. EUTRO sub-programs will be used to analyze the eutrophication model due to the nutrient compound of a dynamic dissolved oxygen. EUTRO program has a method to solve a given program depending on the quantity of introduced variables. It models classic pollution indicators which include dissolved oxygen, biochemical oxygen demand, nitrogen compounds, phosphorus compounds, temperature, and coli bacteria content. WASP model is a numerical model by using a finite difference method to solve the mass balance equation from the pollutant, kinetic equation, and transport equation on its time simulation stages. After that, the WASP can manage its time simulation stages, to make sure the stability of the model.

The basic principle of both the hydrodynamics and water-quality program is the conservation of mass. The water volume and water-quality constituent masses being studied are tracked and accounted for over time and space using a series of mass balancing equations. The hydrodynamics program also conserves momentum, or energy, throughout time and space. The basic formula that is solved by the WASP program is the mass balance equation:

$$
\frac{\partial C}{\partial \mathrm{t}}(A C)=\frac{\partial}{\partial x}\left(-U_{x} A C+E_{x} A \frac{\partial C}{\partial x}\right)+A\left(S_{L}+S_{B}\right)+A S_{K}
$$

where:

$\mathrm{C}$ : concentration of the water quality constituent $\left(\mathrm{mg} / \mathrm{L} \mathrm{or} \mathrm{g} / \mathrm{m}^{3}\right)$

t: time (days)

$\mathrm{U}_{\mathrm{x}}$ : Iongitudinal, lateral, and vertical advective velocities ( $\mathrm{m} /$ day)

$E_{x}$ : longitudinal, lateral, and vertical diffusion coefficients ( $\mathrm{m}^{2} /$ day)

A: cross-sectional area $\left(\mathrm{m}^{2}\right)$

$\mathrm{S}_{\mathrm{L}}$ : direct and diffuse loading rate $\left(\mathrm{g} / \mathrm{m}^{3}\right.$-day $)$

$S_{B}$ : boundary loading rate (including upstream, downstream, benthic, and atmospheric $\left(\mathrm{g} / \mathrm{m}^{3}\right.$-day) 
$\mathrm{S}_{\mathrm{K}}$ : total kinetic transformation rate; positive is source, negative is sink $\left(\mathrm{g} / \mathrm{m}^{3}\right.$-day)

The WASP model is using a model network as a set of expanded control volumes or "segments" that together represent the physical configuration of the water body. The network may subdivide the water body laterally and vertically as well as longitudinally. Concentrations of water quality constituents are calculated within each segment. Transport rates of water quality constituents are calculated across the interface of the adjoining segment.

\section{Results}

The model will be calibrated to estimate the parameters or coefficient from the comparison of field observation and model results. After that, the parameters will be tested with other observation data, namely the verification process. The calibration process will be evaluated by using Root Mean Square Error (RMSE) while the verification process will be evaluated by calculating the percent difference between observation and model outputs. From the result of the calibration, it was found that the value of the reaeration coefficient range between $0.08-0.15$ day $^{-1}$ while for the BOD decay rate and phosphorus mineralization rate constant were $0.0004 \mathrm{day}^{-1}$ respectively. Due to the weak hydrodynamic, the reaeration coefficient is relatively small especially in the middle of the dam. In the upstream zone or at the location whereas the inflow water enters the dam, the reaeration coefficient is relatively higher than in the middle of the dam. Additionally, this weak hydrodynamic also causes the value of decay rate for BOD and phosphorus mineralization rate constant to have small values. From the RMSE errors, the minimum value for DO, TP, and BOD were $0.014,0.054$, and 0.883 for calibration and the percent difference was $0.09 \%$, $0 \%$, and $0.12 \%$ for verification respectively. The calibration results and verification results for DO, TP, and BOD can be seen in Figure 2 to Figure 9 and Figure 10 to Figure 17 respectively. Based on the results above, it can be seen that the evaluation model results are relatively small. Therefore, the model is reliable to use for further development such as pollution control. As mentioned by Alfonsus et al (2018), disposing of the wastewater in an environmentally acceptable manner can be an effective solution towards water pollution control. In the control selection scenario, fish farm loads are easier to be controlled than domestic wastewater so that the scenarios will be applied gradually starting from control of the fish farms and later domestic wastewater. The pollution control scenario will consist of 8 scenarios that can be seen in Table 2. From the simulation results from scenario 1 to scenario 3 show the control of the fish farm load was able to reduce the TP concentration significantly but slightly reduced for DO and BOD concentration. Therefore, from scenario 1 to scenario 3 will be combined by adding $20 \%$ control to domestic wastewater and become scenario 4 to scenario 6. However, the DO and BOD concentration value still exceed the maximum value for the raw water standard of Indonesia. The last scenario (scenario 7 and scenario 8) will be implemented by increasing the domestic wastewater control up to 50 $\%$ and $100 \%$ respectively. The simulation results for each point can be seen in Figure 18 to Figure 25 respectively. 


\begin{tabular}{|ll|}
\hline Scenario & Description \\
\hline 1 & Control $50 \%$ load of fish farm \\
\hline 2 & Control $80 \%$ load of fish farm \\
\hline 3 & Control $100 \%$ load of fish farm \\
\hline 5 & Control $50 \%$ load of fish farm $+20 \%$ domestic waste water \\
\hline 6 & Control $80 \%$ load of fish farm $+20 \%$ domestic waste water \\
\hline 7 & Control $100 \%$ load of fish farm $+20 \%$ domestic waste water $100 \%$ load of fish farm $+50 \%$ domestic waste water \\
\hline
\end{tabular}

Table 2

Water pollution control scenario

\section{Discussion And Analysis}

As mentioned above, this research is expected to restore the water quality in the dam as its designated use for Class II ( $D O=4 \mathrm{mg} / \mathrm{L}, \mathrm{TP}=0.2 \mathrm{mg} / \mathrm{L}$, and BOD $=3 \mathrm{mg} / \mathrm{L}$ ). Based on the results, scenario 8 provides the best results to control water pollution rather than another scenario. For the TP and BOD concentration, the value was highly enhanced and met the raw water standard. For DO concentration is also improved and it can be seen that on the existing condition, the concentration only exceed the minimum value ( $4 \mathrm{mg} / \mathrm{L})$ started in the beginning of 2017 while in scenario 8 , for point 2 and 6 were started from the early of 2016 and the rest is started in the middle of 2016. In its application for scenario 8 , there are some difficulties in the implementation due to several factors such as economic factors, environmental factors, etc. but this model will be an illustration when implemented.

\section{Conclusion}

The RMSE value and percent difference provides satisfying results for DO, BOD, and TP during the calibration and verification process $(0.014,0.054$, and 0.883 for calibration and $0.09 \%, 0 \%$, and $0.12 \%$ respectively). The water pollution control in Duriangkang Dam by using scenario 8 gives the best results than other scenarios. The maximum concentration for TP and BOD does not exceed the maximum value for the raw water standard of Indonesia. However, due to the drought year starting from 2014 to 2016, the results for DO shows that in early 2016 the DO concentration was lower than the minimum value and continued to increase from the middle of 2016 (for points 2 and 6 starting from early of 2016), the DO concentrations exceeded the minimum value.

\section{Recommendation}


There are some limitations in this study such as no information for the geometry data, inflow discharge, and water quality from Duriangkang Catchment. Besides that, no water quality data from the outflow of Muka Kuning Dam (in 2016 to 2018). Moreover, the sampling locations are not evenly distributed along the dam and the water sampling should be taken from various depths to know the water quality distribution along the dam layer.

\section{Declaration}

\section{AVAILABILITY OF DATA AND MATERIAL}

The datasets used and/or analysed during the current study are available from the corresponding author on reasonable request.

\section{COMPETING INTEREST}

The authors declare that they have no competing interests.

\section{FUNDINGS}

The authors received no financial support for the research, authorship, and/or publication of this article.

\section{AUTHORS' CONTRIBUTIONS}

CW analyzed, built the WASP model, wrote the manuscript. DY provided the data, gave comments and suggestions. GY gave comments and suggestions.

\section{ACKNOWLEDGEMENT}

Many thanks to Dr. Doddi Yudianto from Parahyangan Catcholic University and Dr. Guan Yiqing from Hohai University for their help in compiling this paper.

\section{References}

1. Alfonsus, C.A., Yudianto, D., Yiqing, G. 'DO SAG-Curve Modeling Using HEC-RAS V.4.1.0: Case Study Surabaya River.' $21^{\text {st }}$ IAHR-APD (2018): 727-735.

2. Ambrose, R.B. et al. 1988. WASP4, A Hydrodynamic and Water Quality Model-Model Theory, User's Manual, and Programmer's Guide. U.S. Environmental Protection Agency, Athens, GA. EPA/600/387-039. 
3. Balcerzak, W. 'The Protection of Reservoir Water against the Eutrophication Process, Institute of Water Supply and Environmental Protection', Kraków University of Technology, ul. Warszawska 24, 31-155 Kraków, Poland, Polish Journal of Environmental Studies, Vol. 15 No. 6 (2006): 837-844.

4. Carpenter, S.R., Caraco, N.F., Correll, D.L., Howarth, R.W., Sharpley, A.N., Smith, V.H. 'Nonpoint Pollution of Surface Waters with Phosphorus and Nitrogen', Ecological Application, 8(3), (1998): 559-568.

5. Connolly, J.P., and R. Winfield. 1984. A User's Guide for WASTOX, a Framework for Modeling the Fate of Toxic Chemicals in Aquatic Environments. Part 1: Exposure Concentration. U.S. Environmental Protection Agency, Gulf Breeze, FL. EPA-600/3-84-077.

6. Di Toro, D.M., Fitzpatrick, and R.V. Thomann. 1981, rev. 1983. Water Quality Analysis Simulation Program (WASP) and Model Verification Program (MVP) - Documentation. Hydroscience, Inc., Westwood, NY, for U.S. EPA, Duluth, M.

7. Jarvie, H.P., Whitton, B.A., Neal, C. 'Nitrogen and Phosphorus in East-Coast British Rivers: Speciation, Sources and Biological Significance', Science of Total Environment, Vol. 210-211, (1998): 79-109.

8. Wool T. A., Ambrose R.B., Martin J.L., Comer. E.A. 'Water Quality Analysis Simulation Program (WASP) - version 6.0, Draft: User's Manual', US Environmental Protection Agency, Atlanta G.A (2001).

\section{Figures}

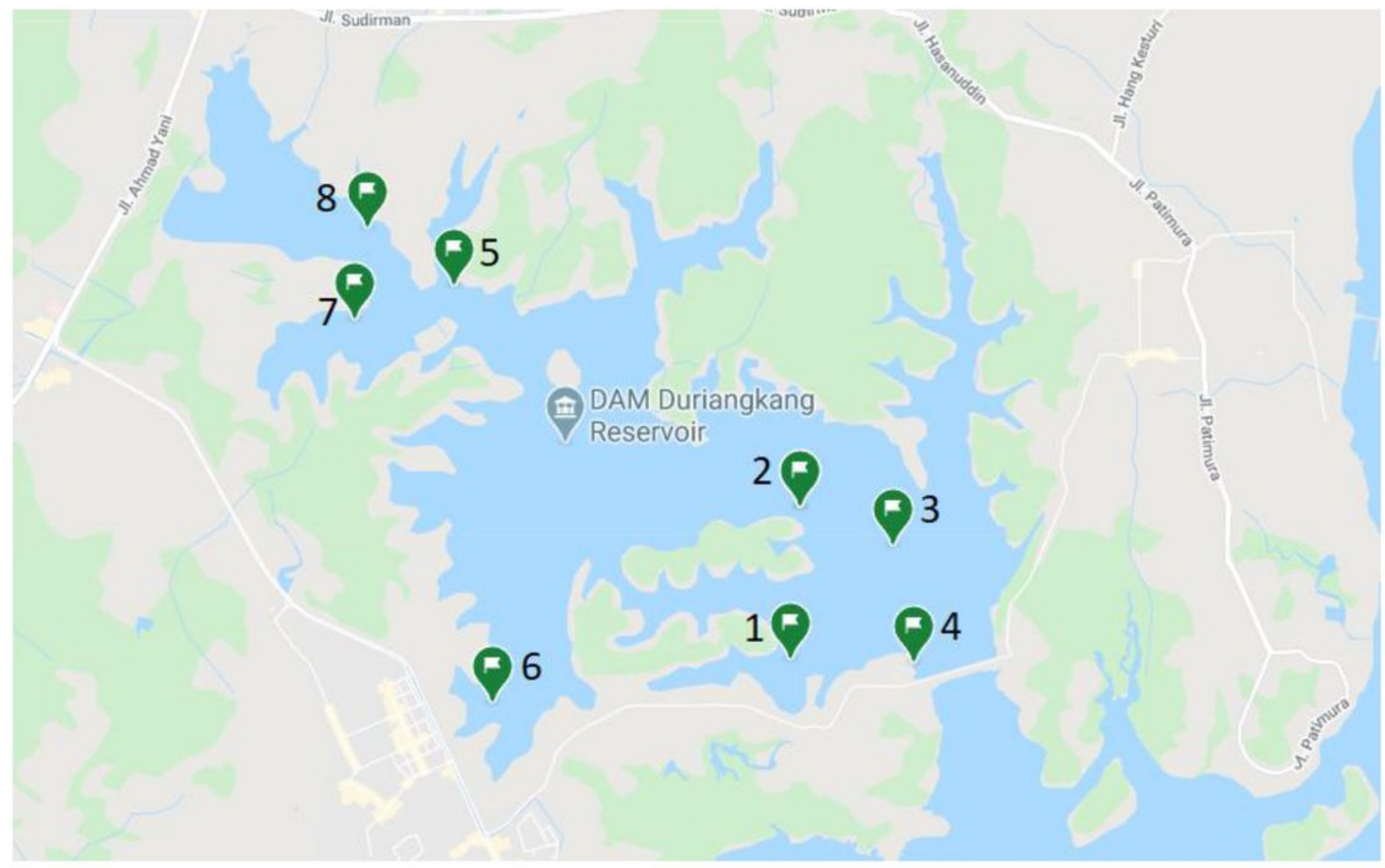


Sampling location
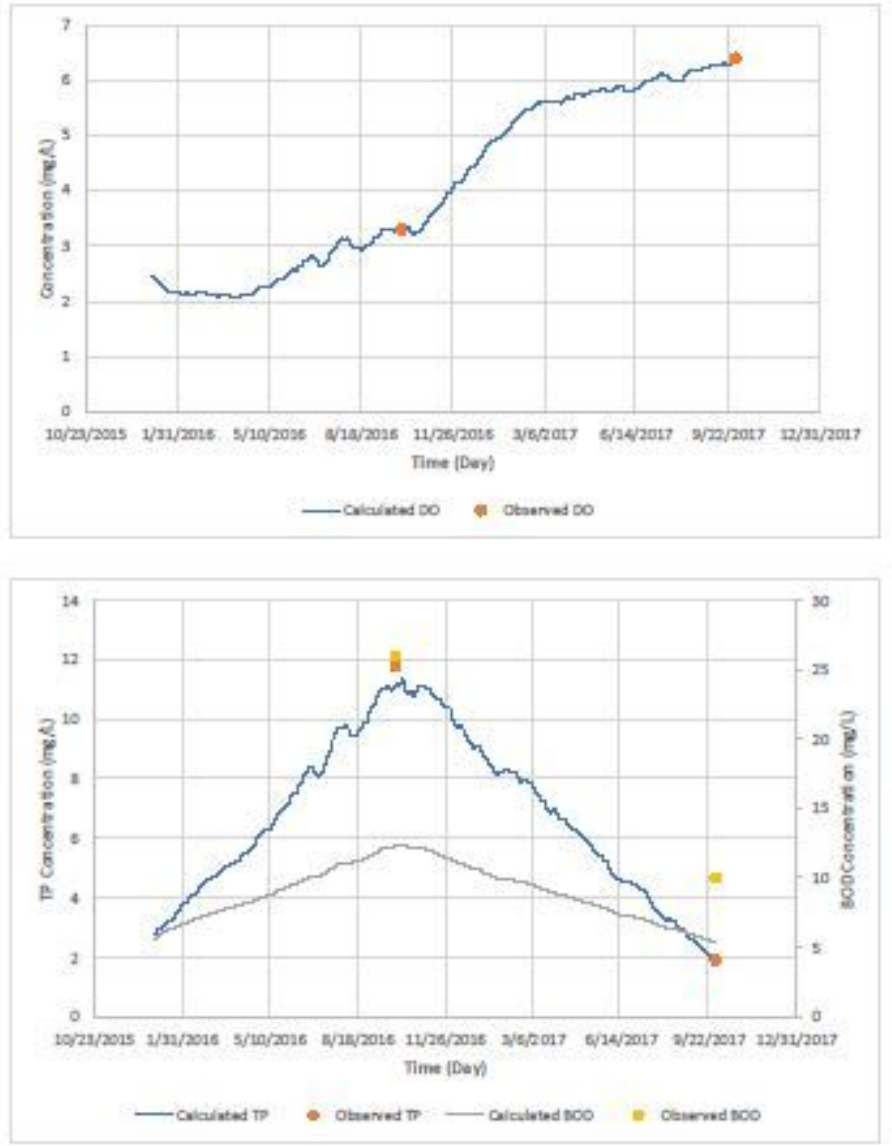

Figure 2

Calibration results for Point 1 

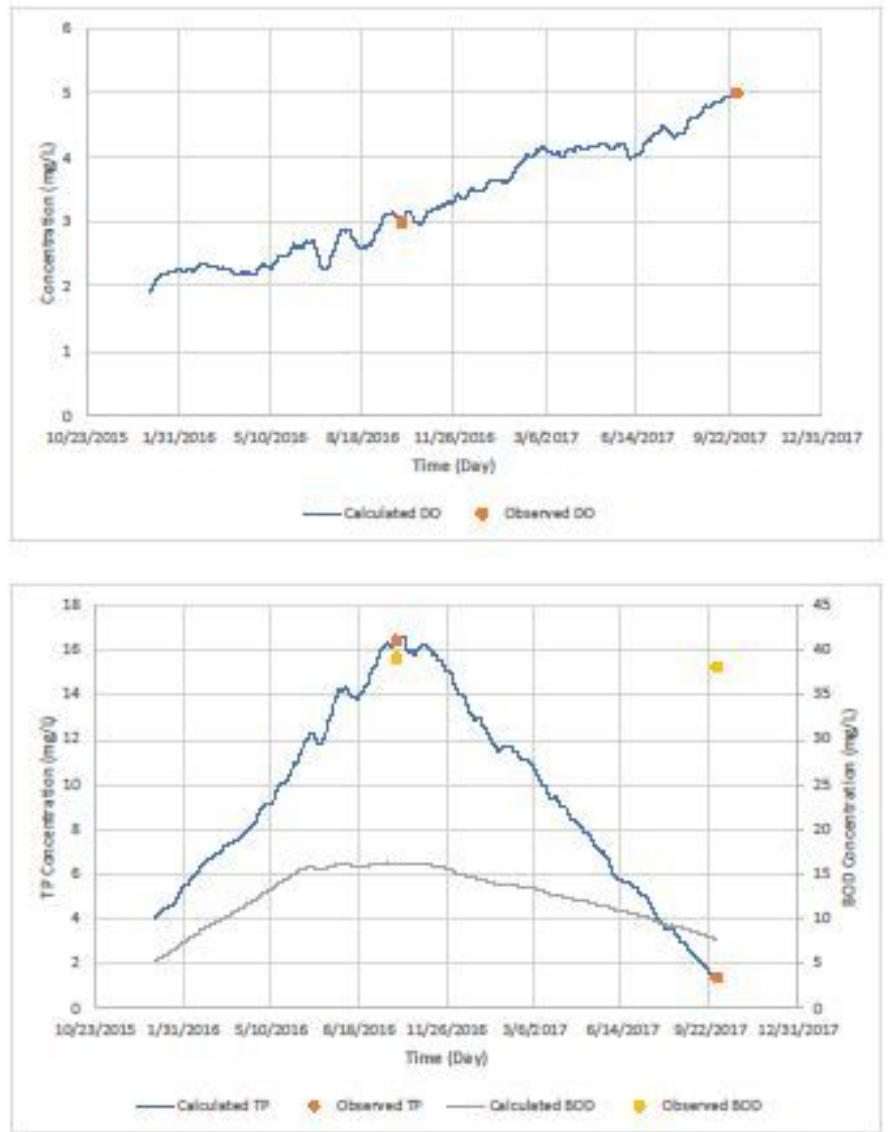

Figure 3

Calibration results for Point 2 

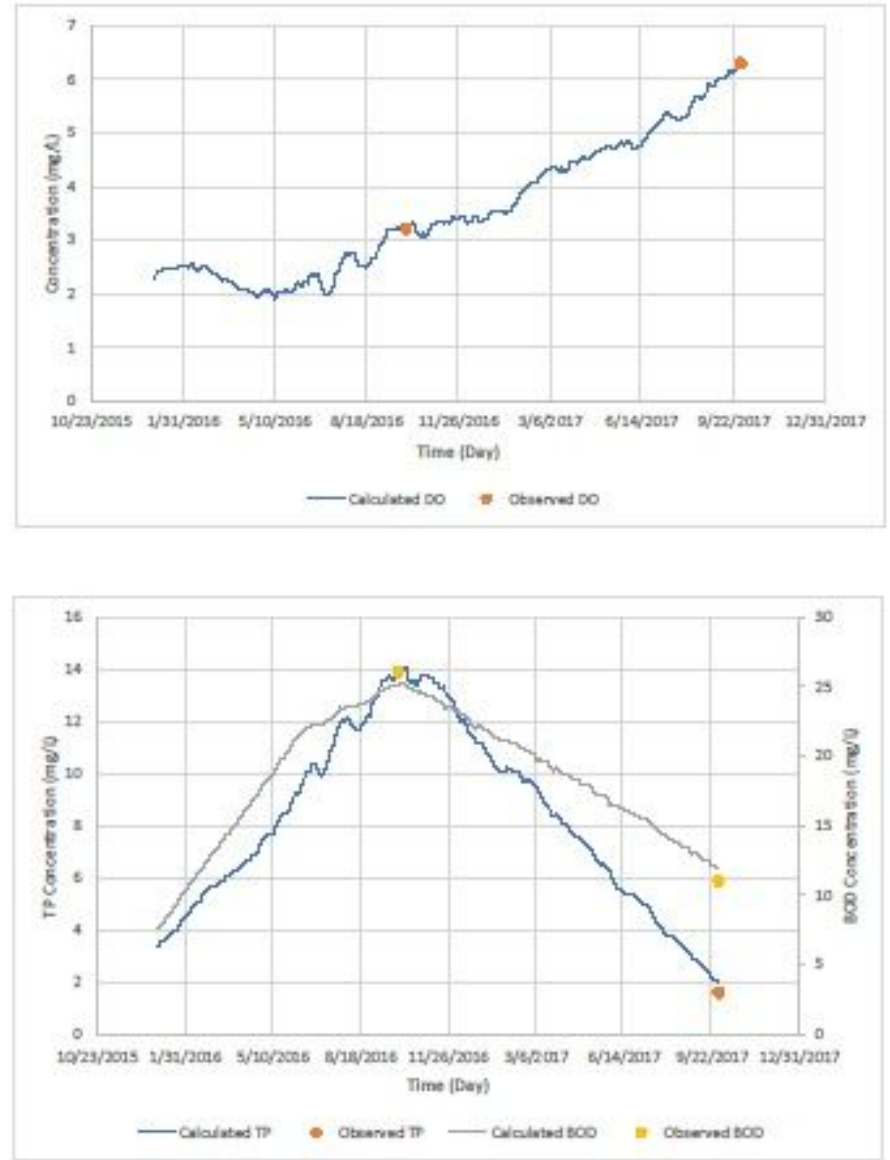

Figure 4

Calibration results for Point 3 

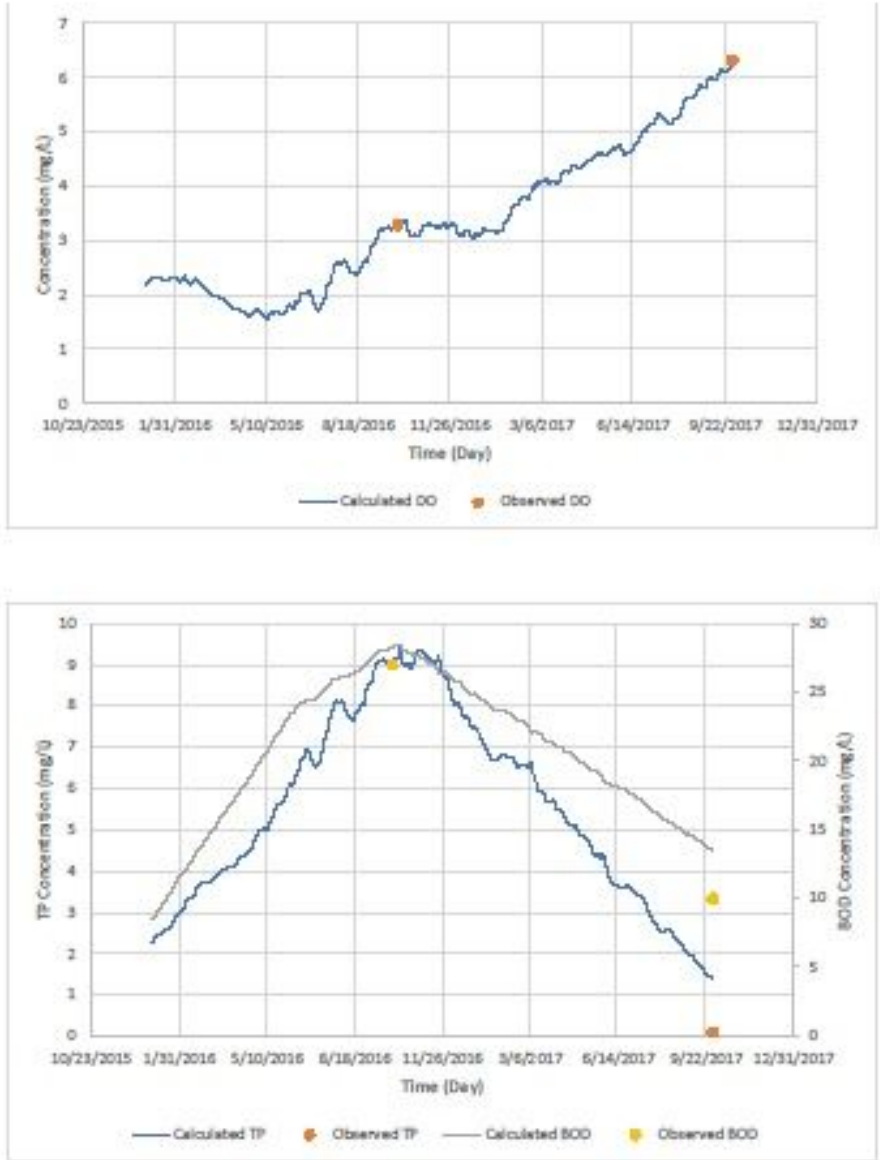

\section{Figure 5}

Calibration results for Point 4 

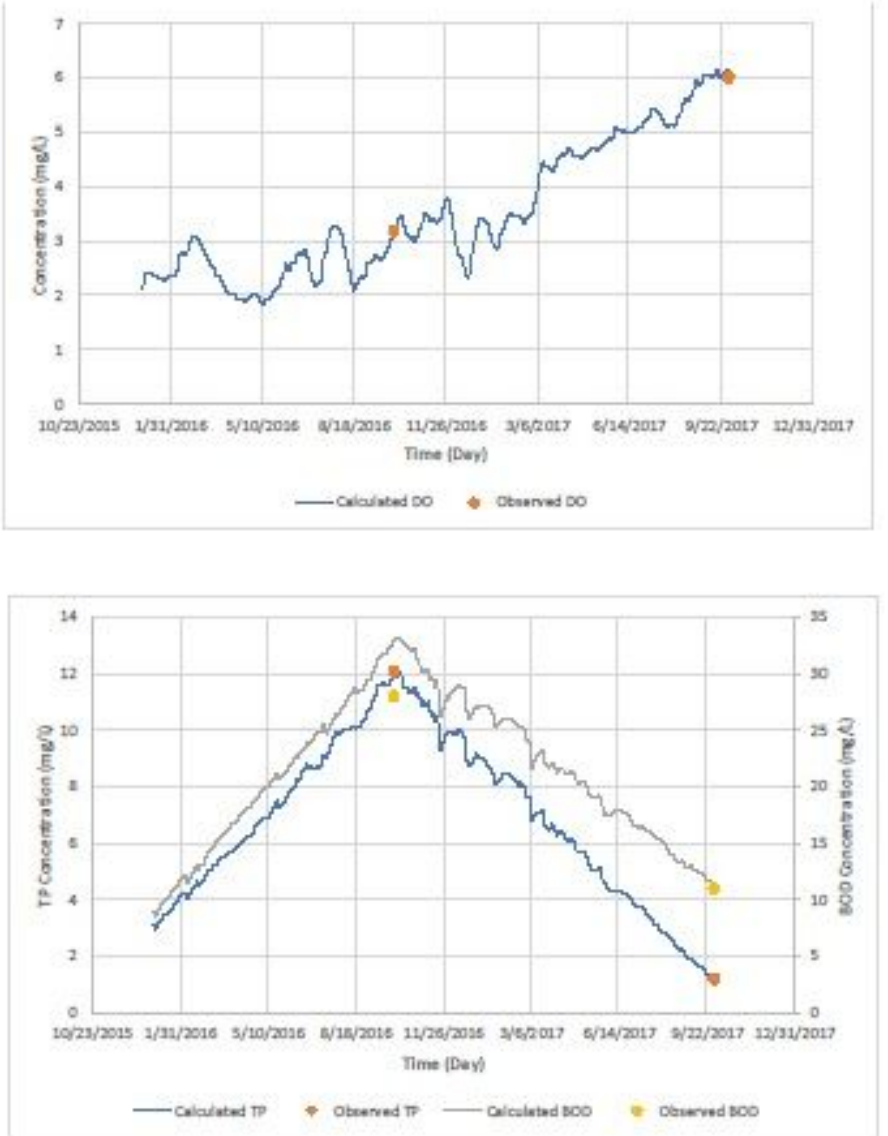

Figure 6

Calibration results for Point 5 

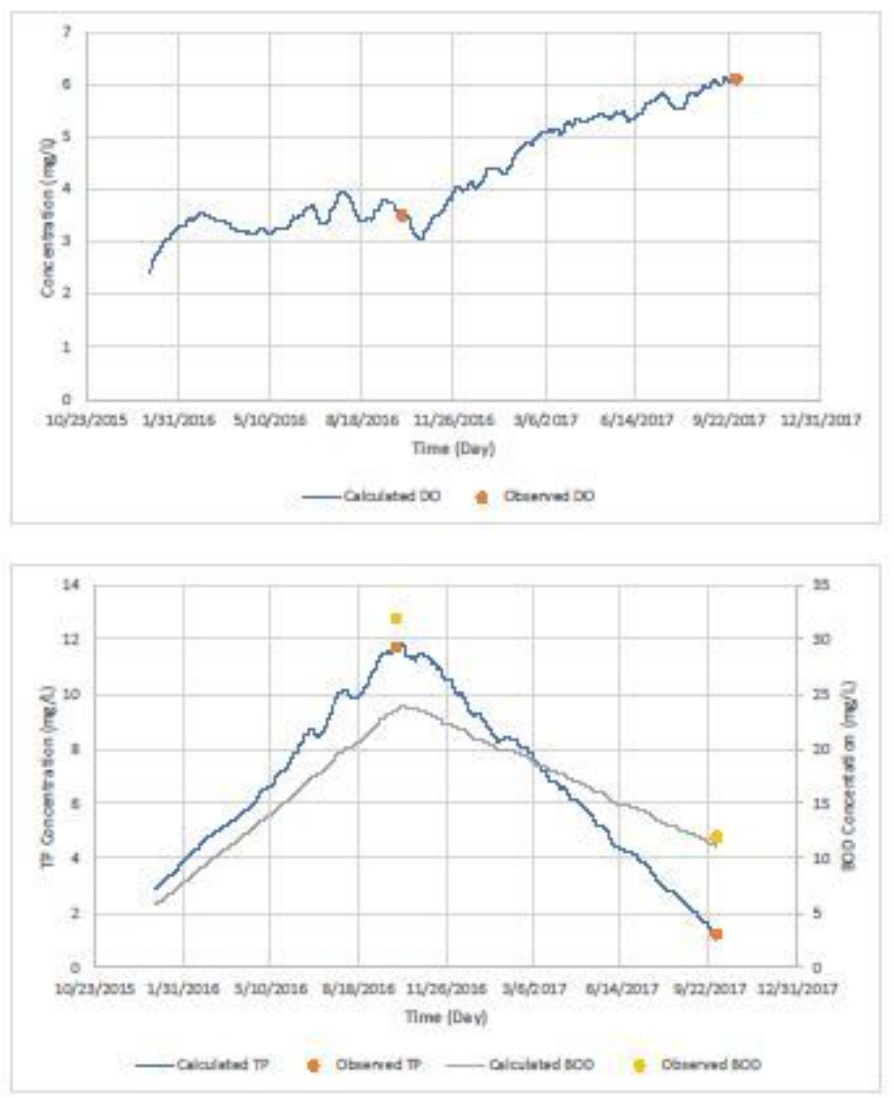

Figure 7

Calibration results for Point 6 

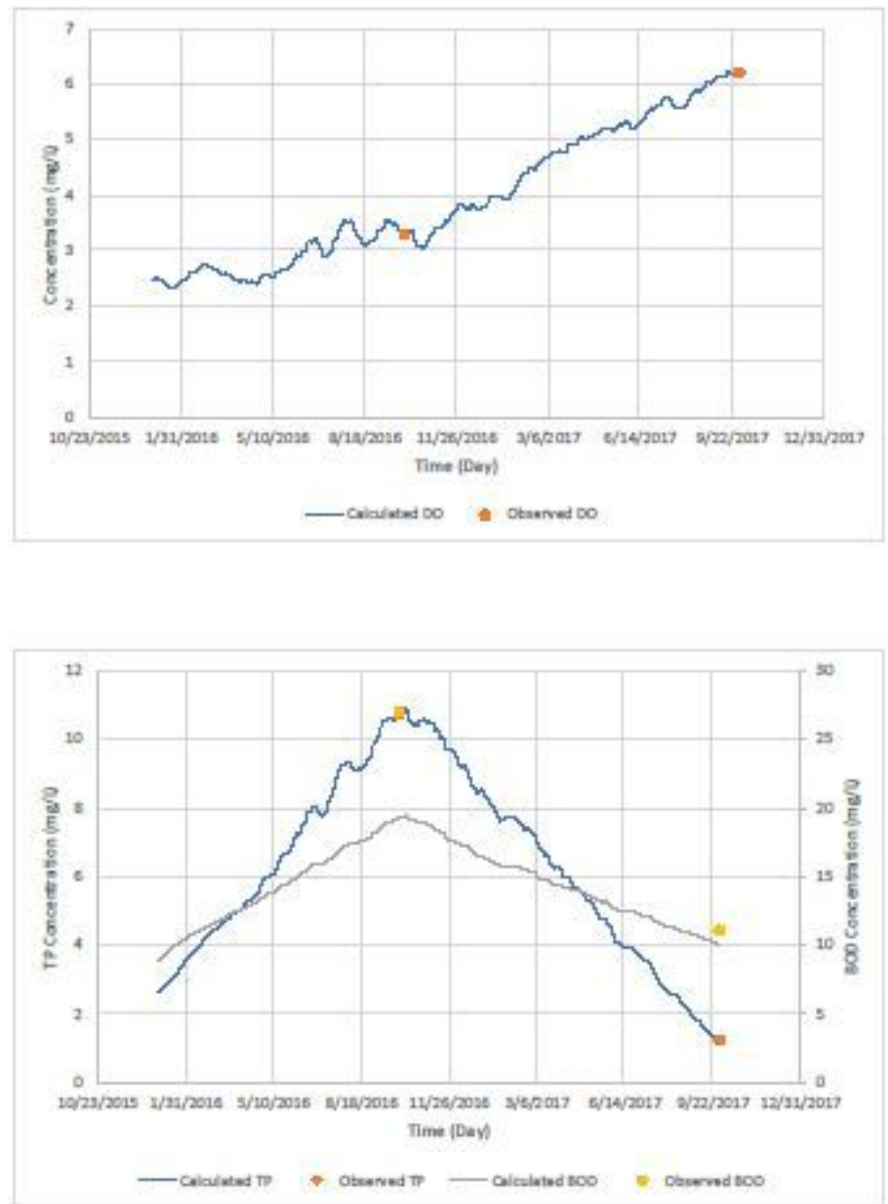

Figure 8

Calibration results for Point 7 

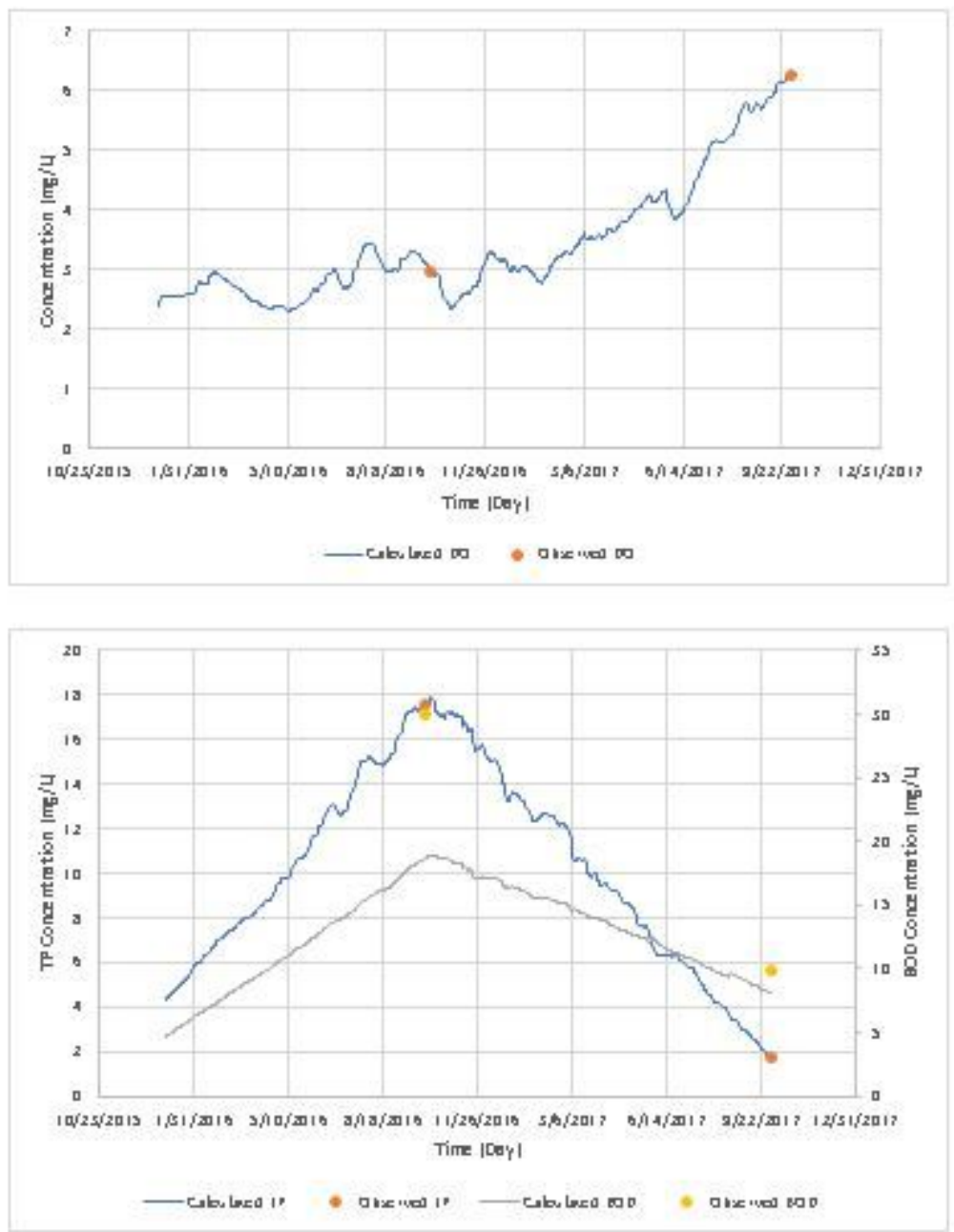

Figure 9

Calibration results for Point 8 

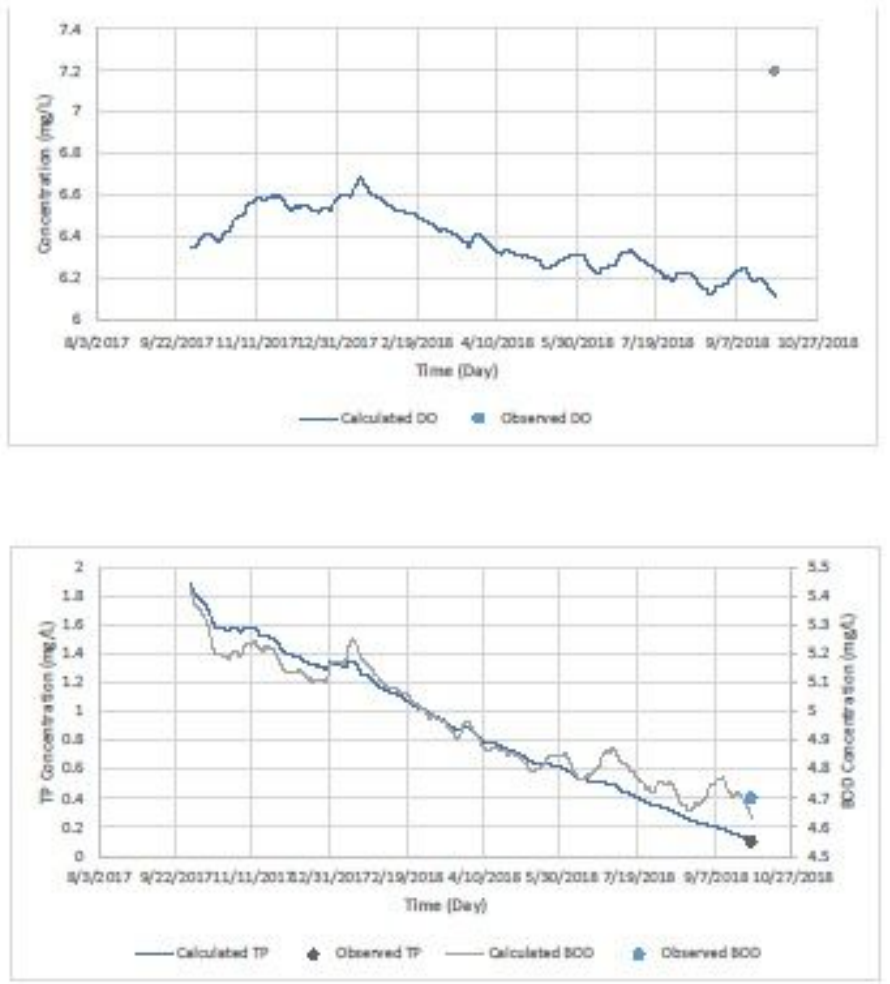

Figure 10

Verification results for Point 1 

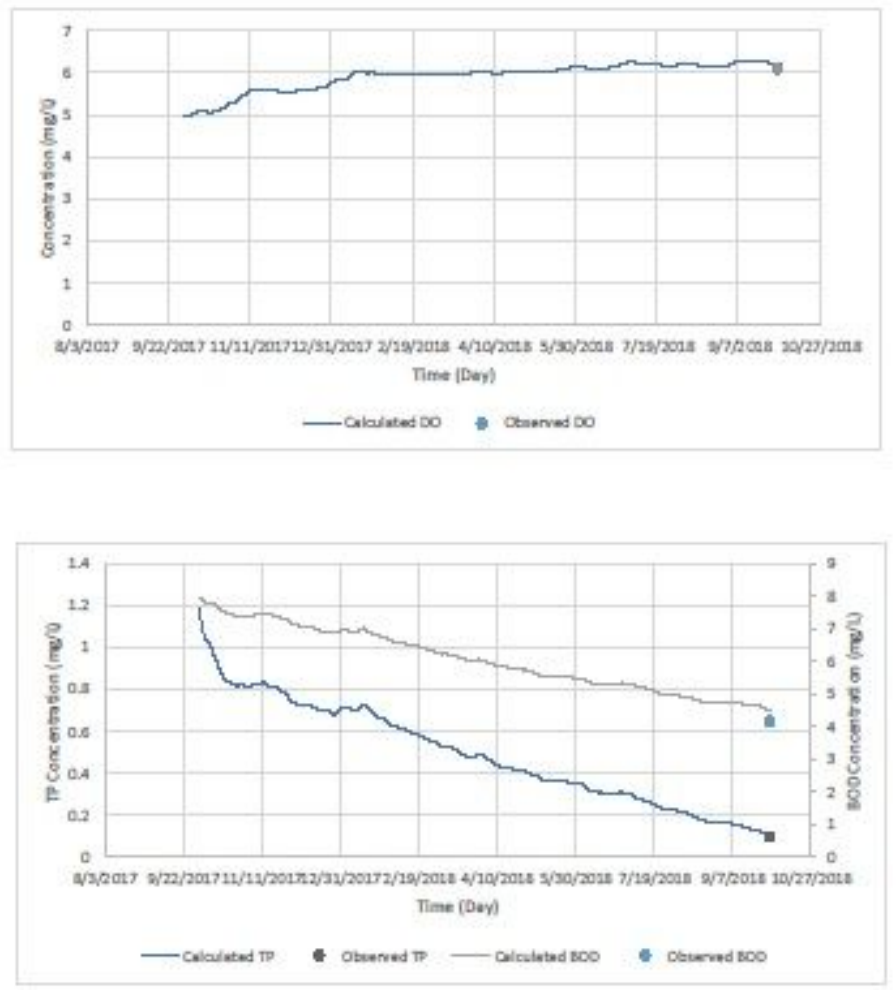

Figure 11

Verification results for Point 2 

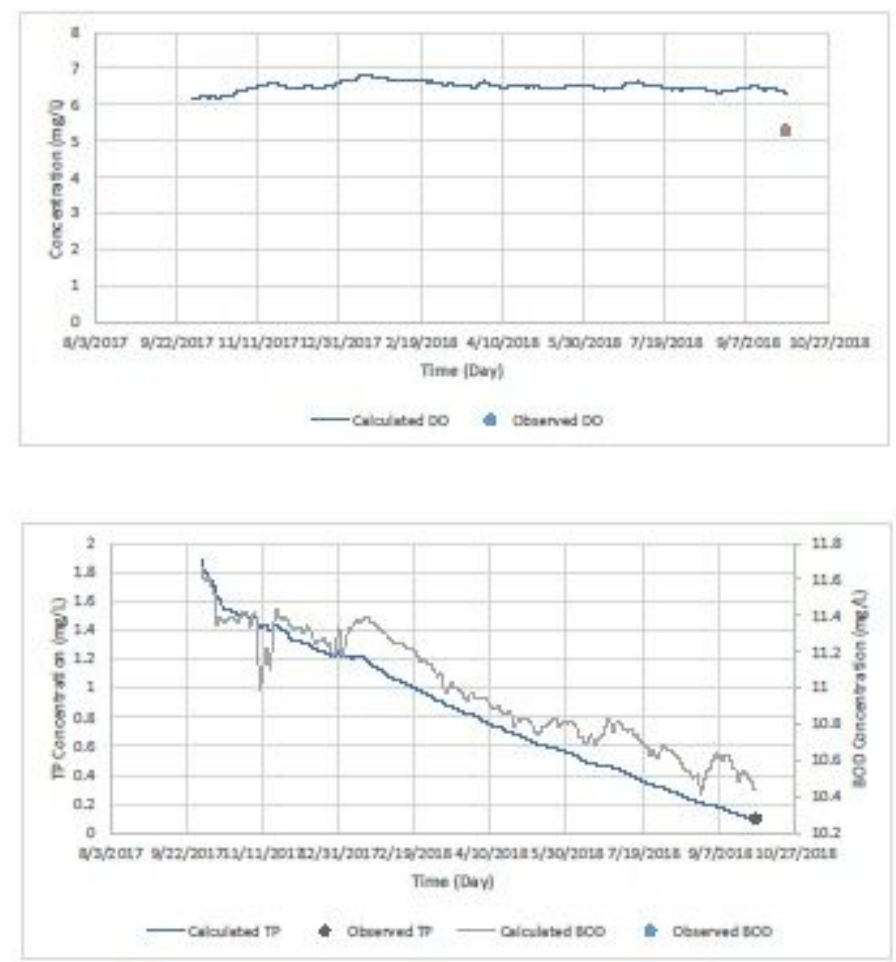

Figure 12

Verification results for Point 3 

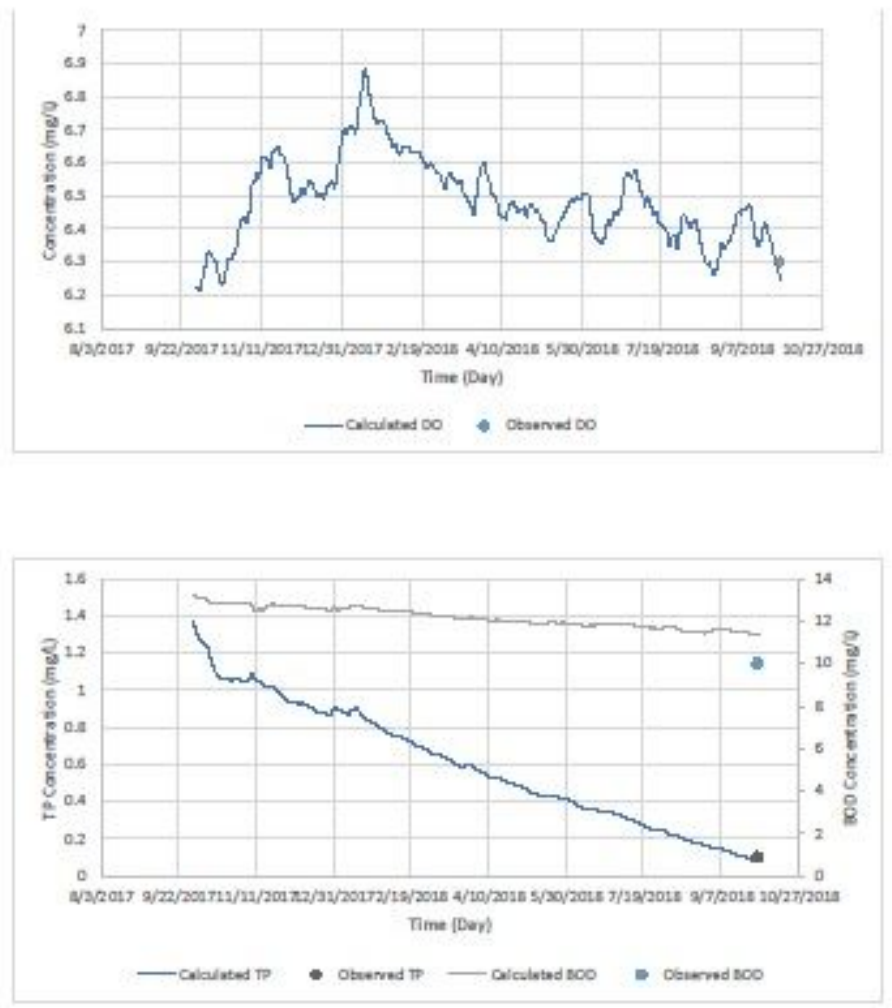

Figure 13

Verification results for Point 4 

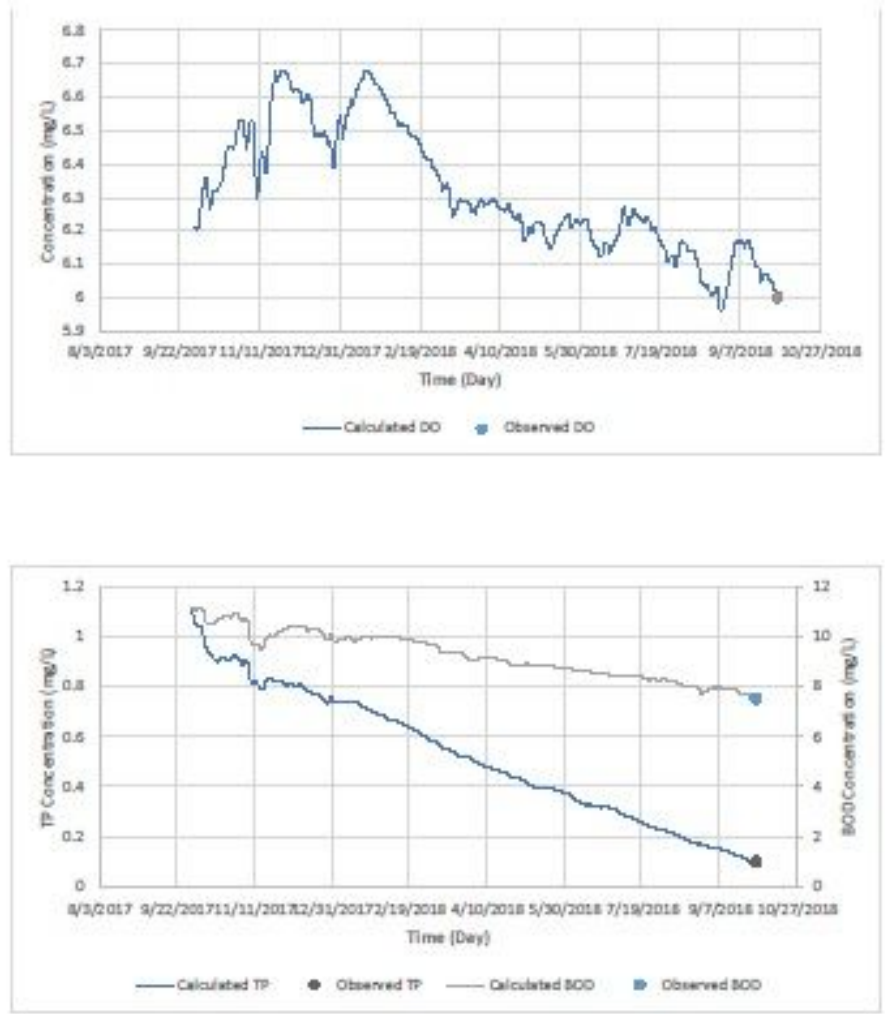

Figure 14

Verification results for Point 5 

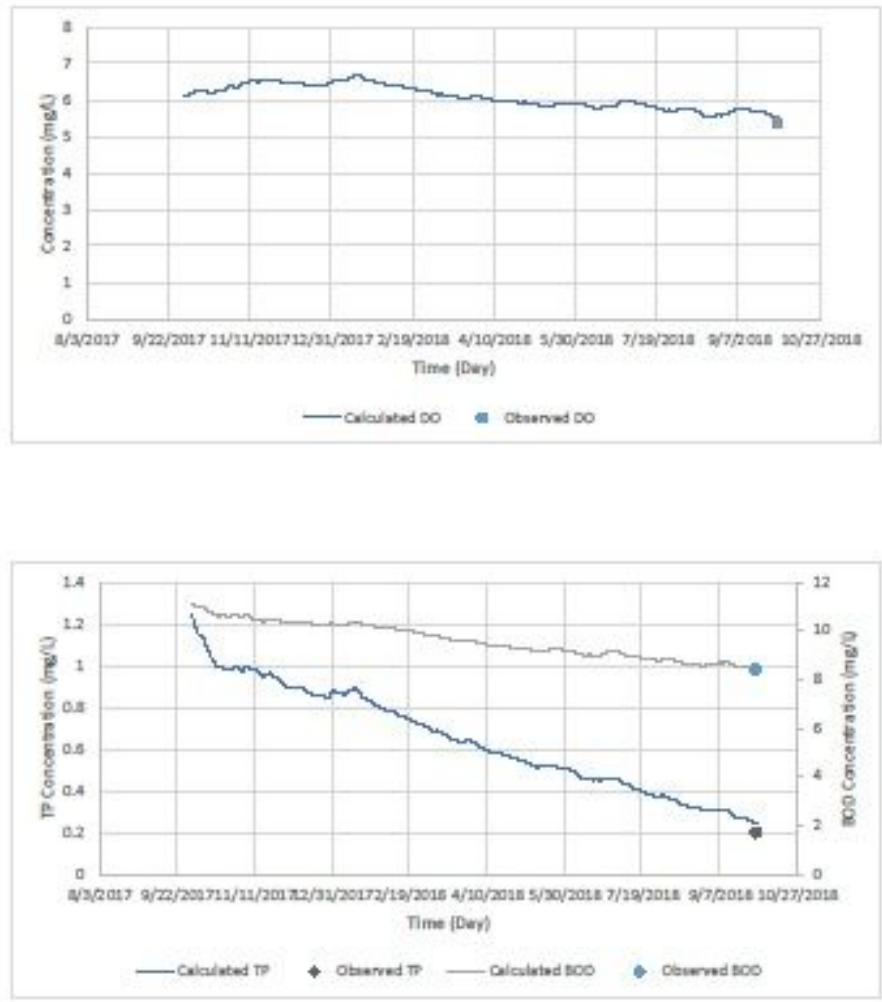

Figure 15

Verification results for Point 6 

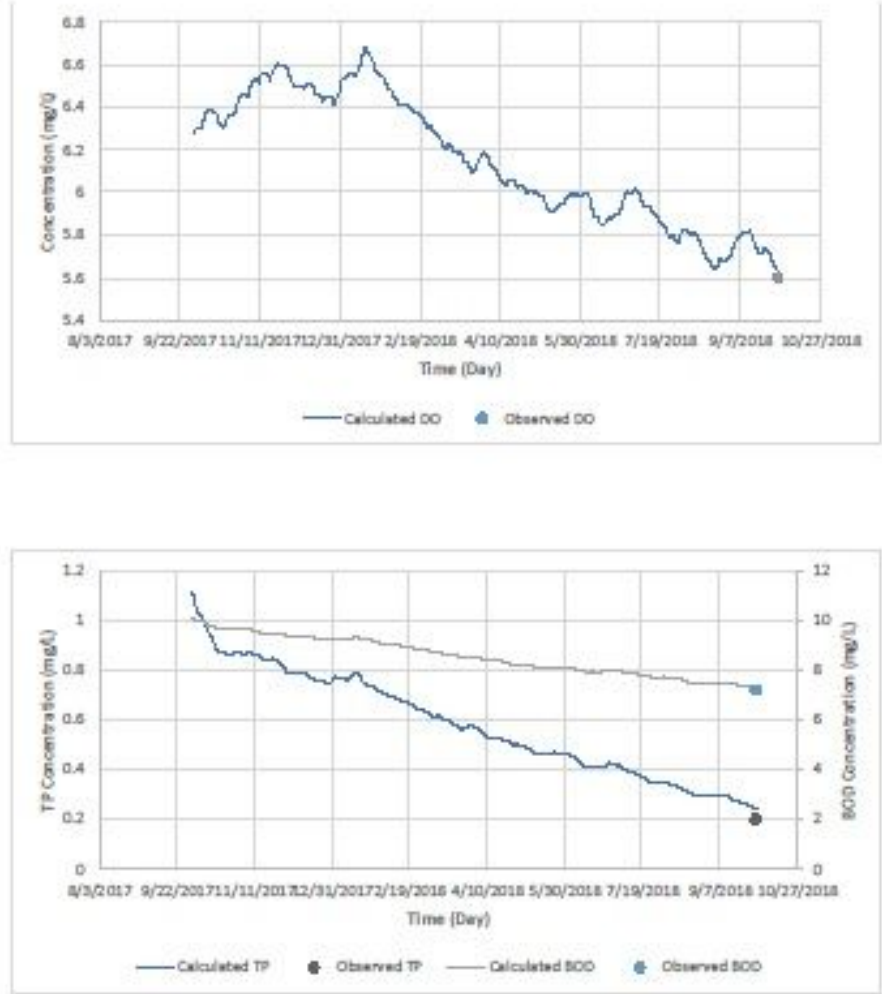

Figure 16

Verification results for Point 7 

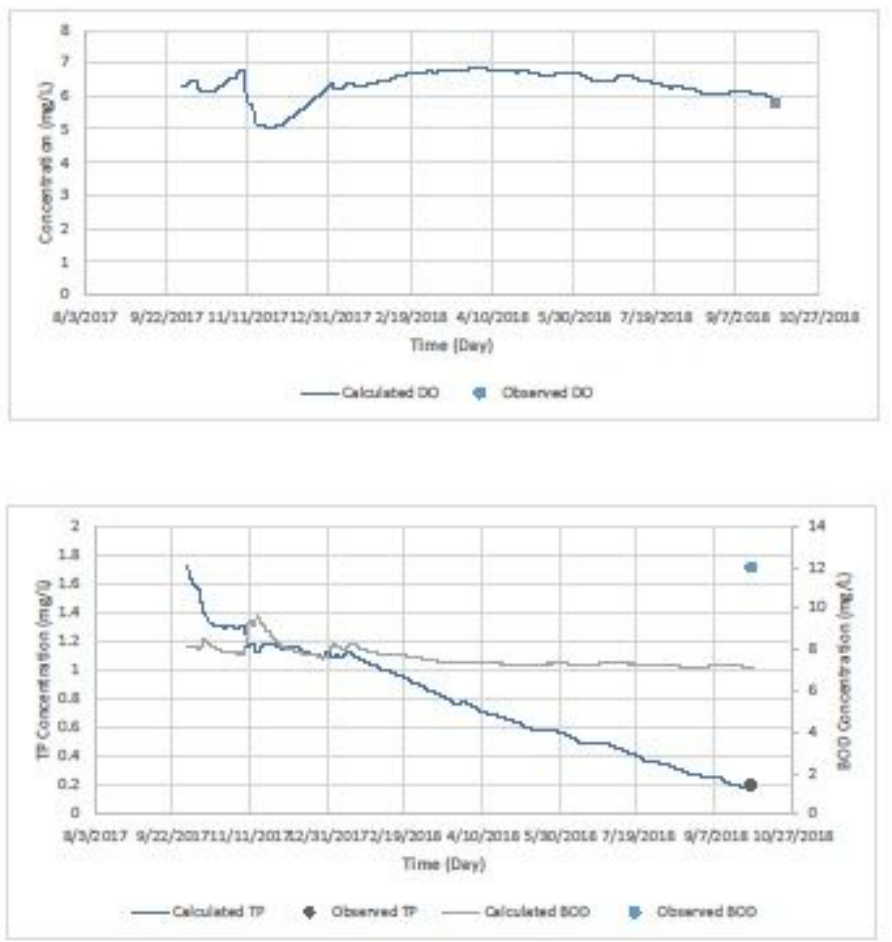

Figure 17

\section{Verification results for Point 8}
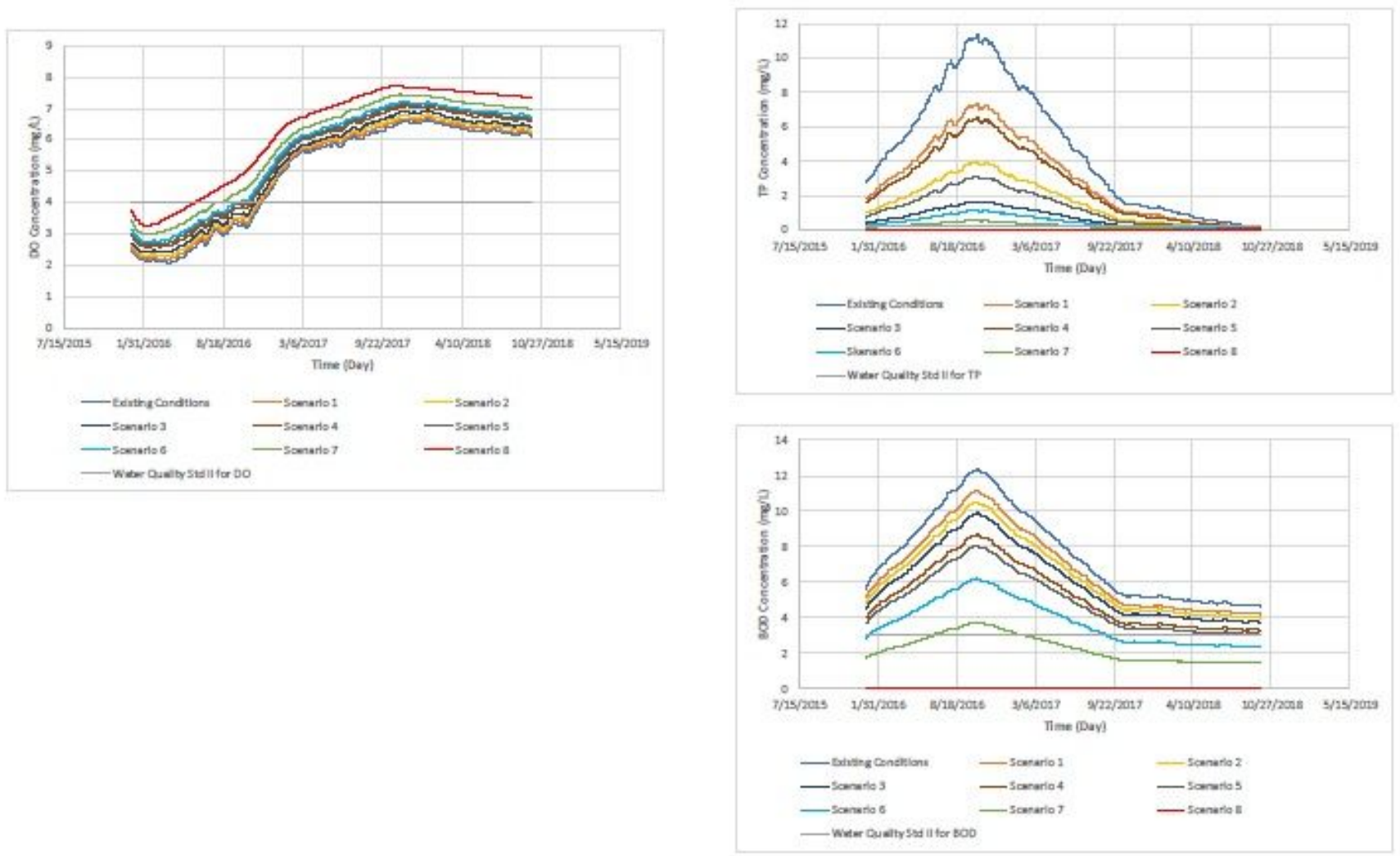
Figure 18

Simulation results for Point 1
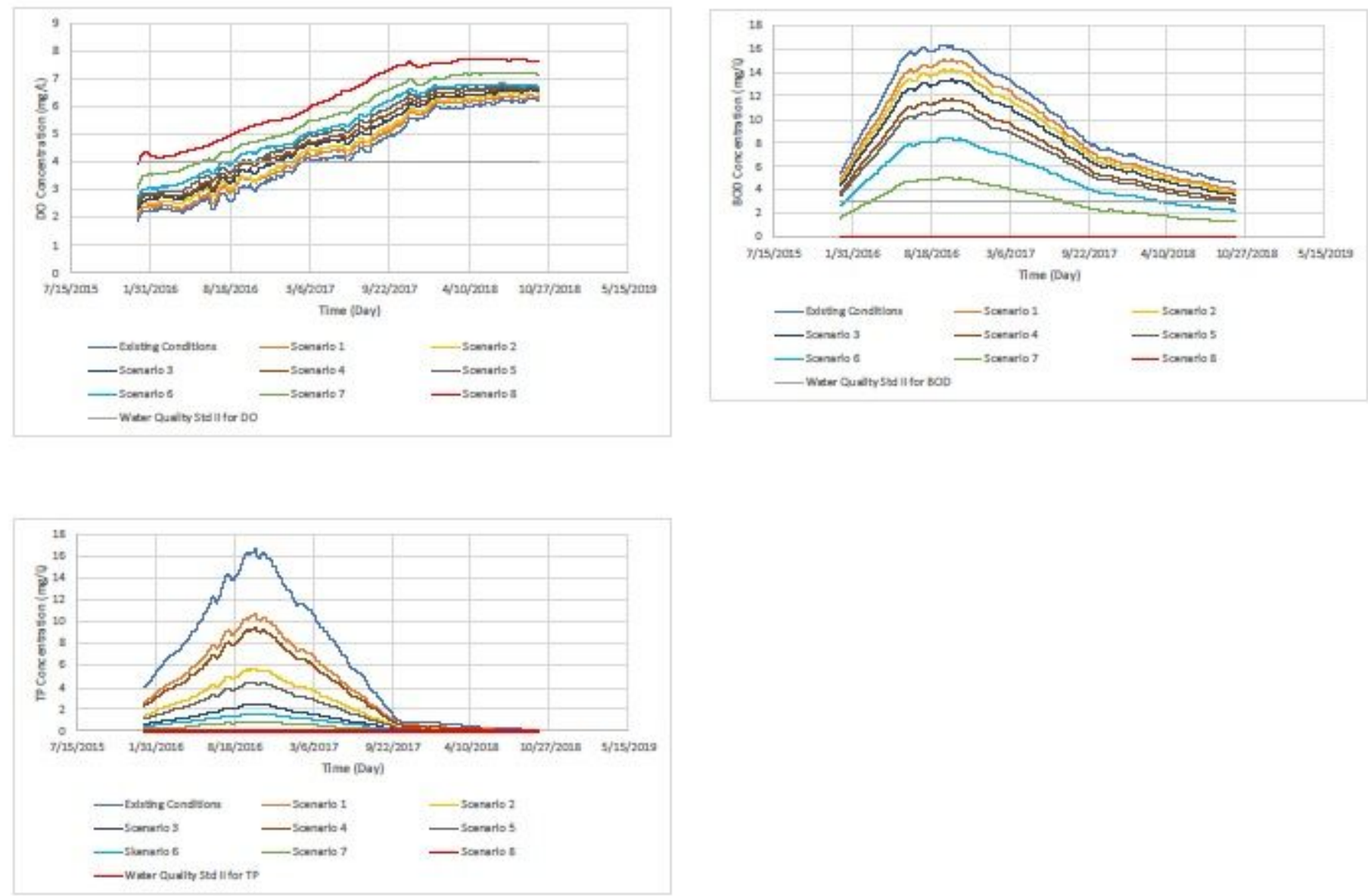

Figure 19

Simulation results for Point 2 

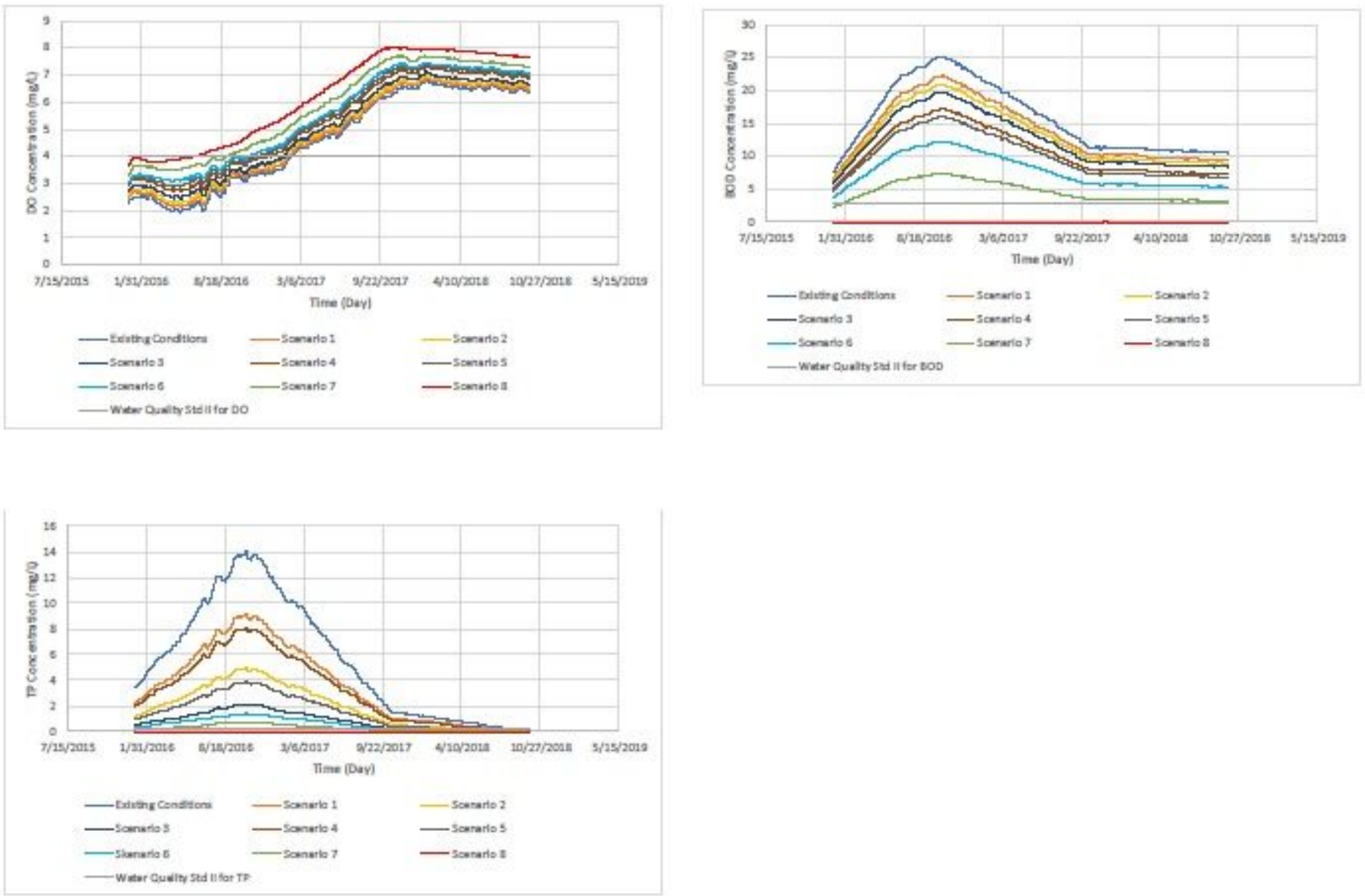

\section{Figure 20}

Simulation results for Point 3 

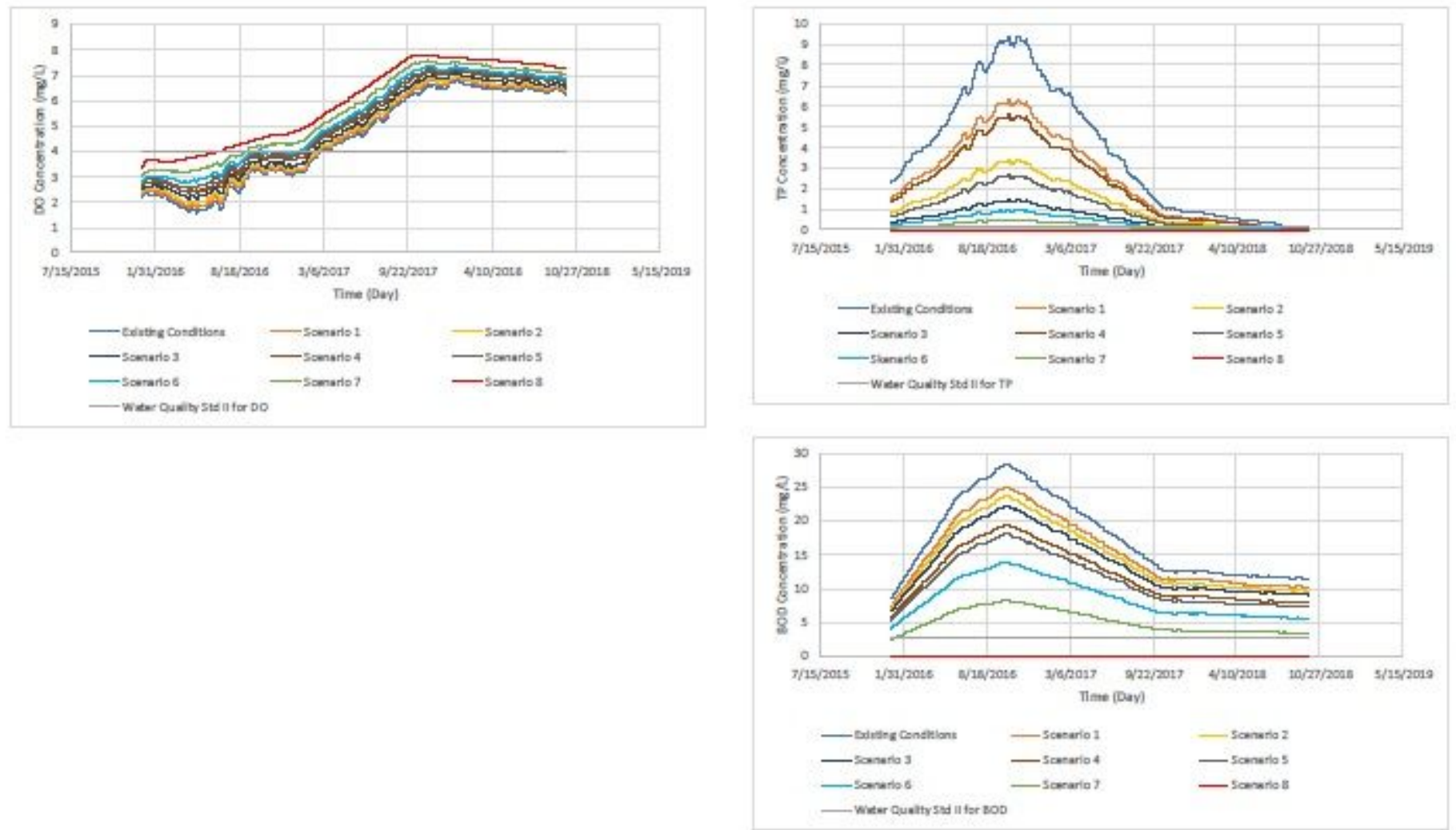

Figure 21

Simulation results for Point 4 

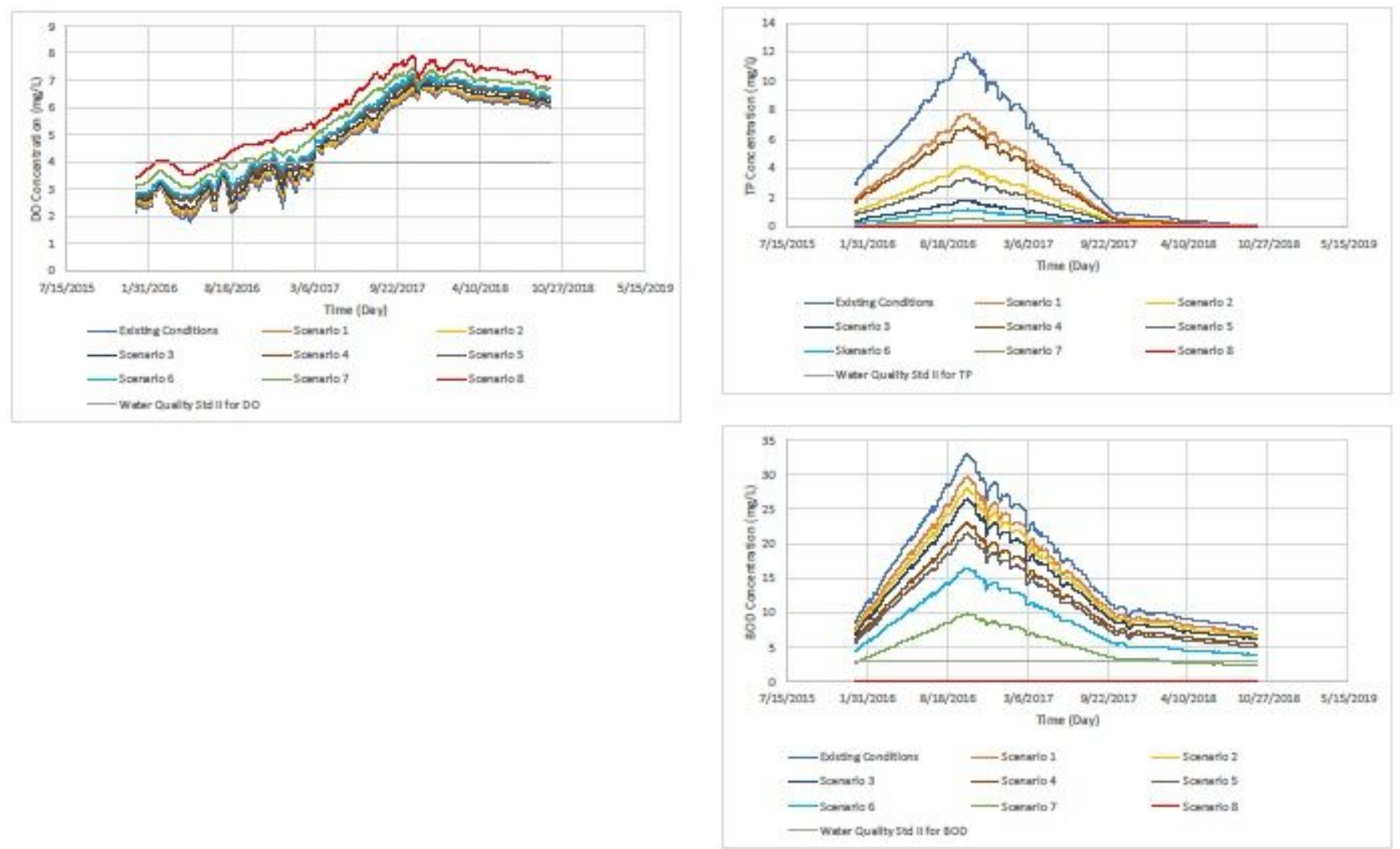

Figure 22

Simulation results for Point 5 

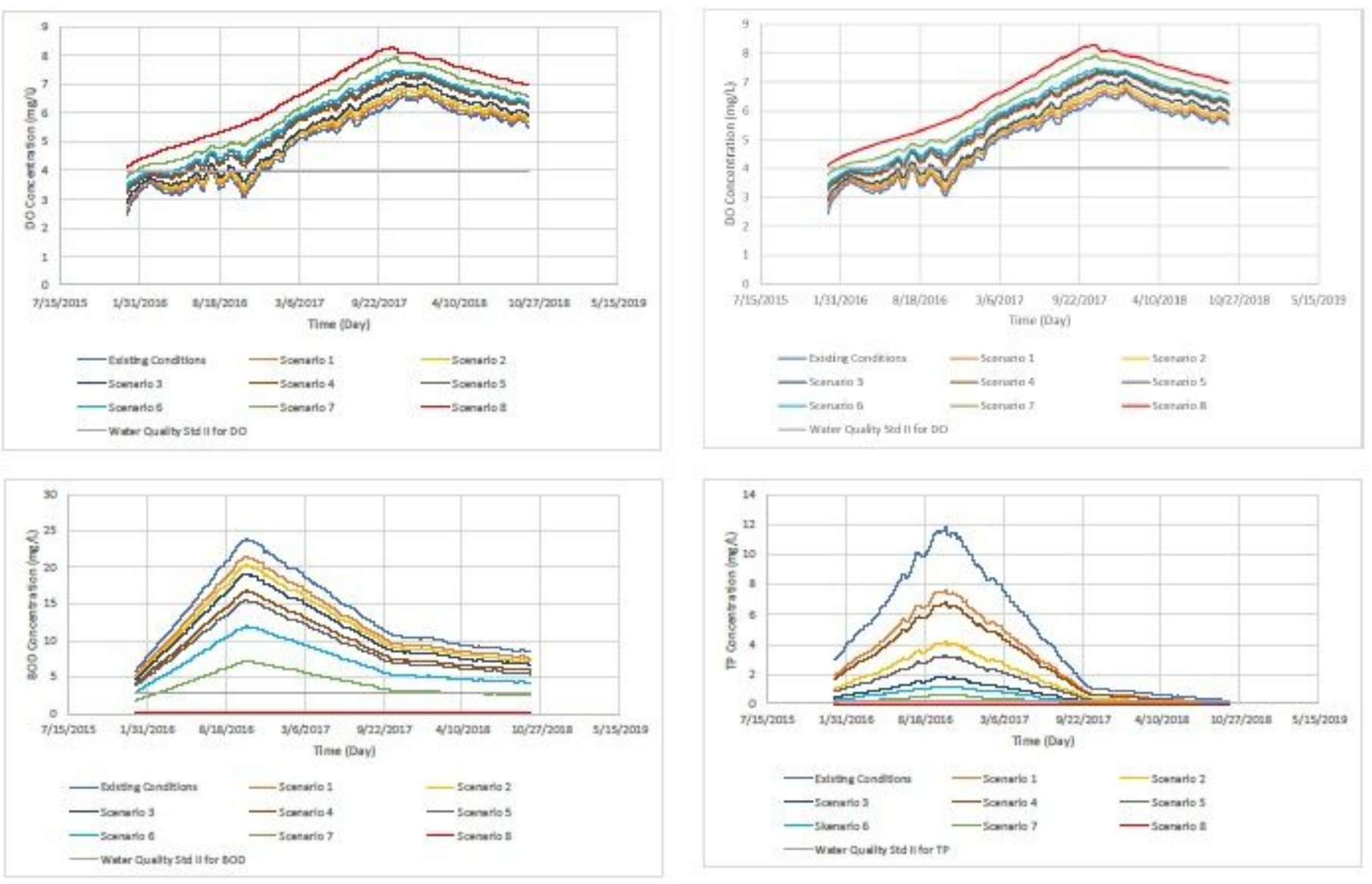

\section{Figure 23}

Simulation results for Point 6 

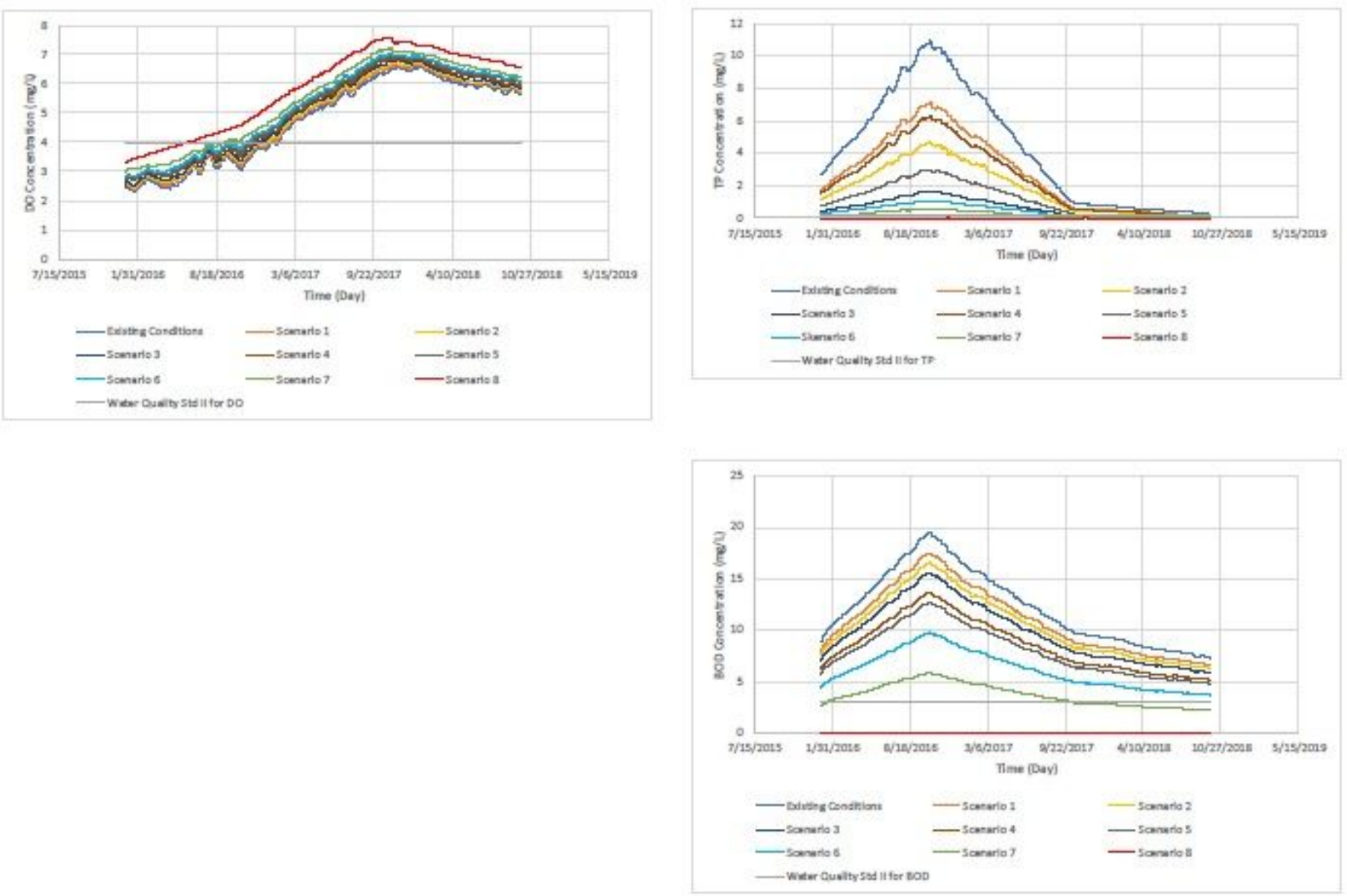

\section{Figure 24}

Simulation results for Point 7 

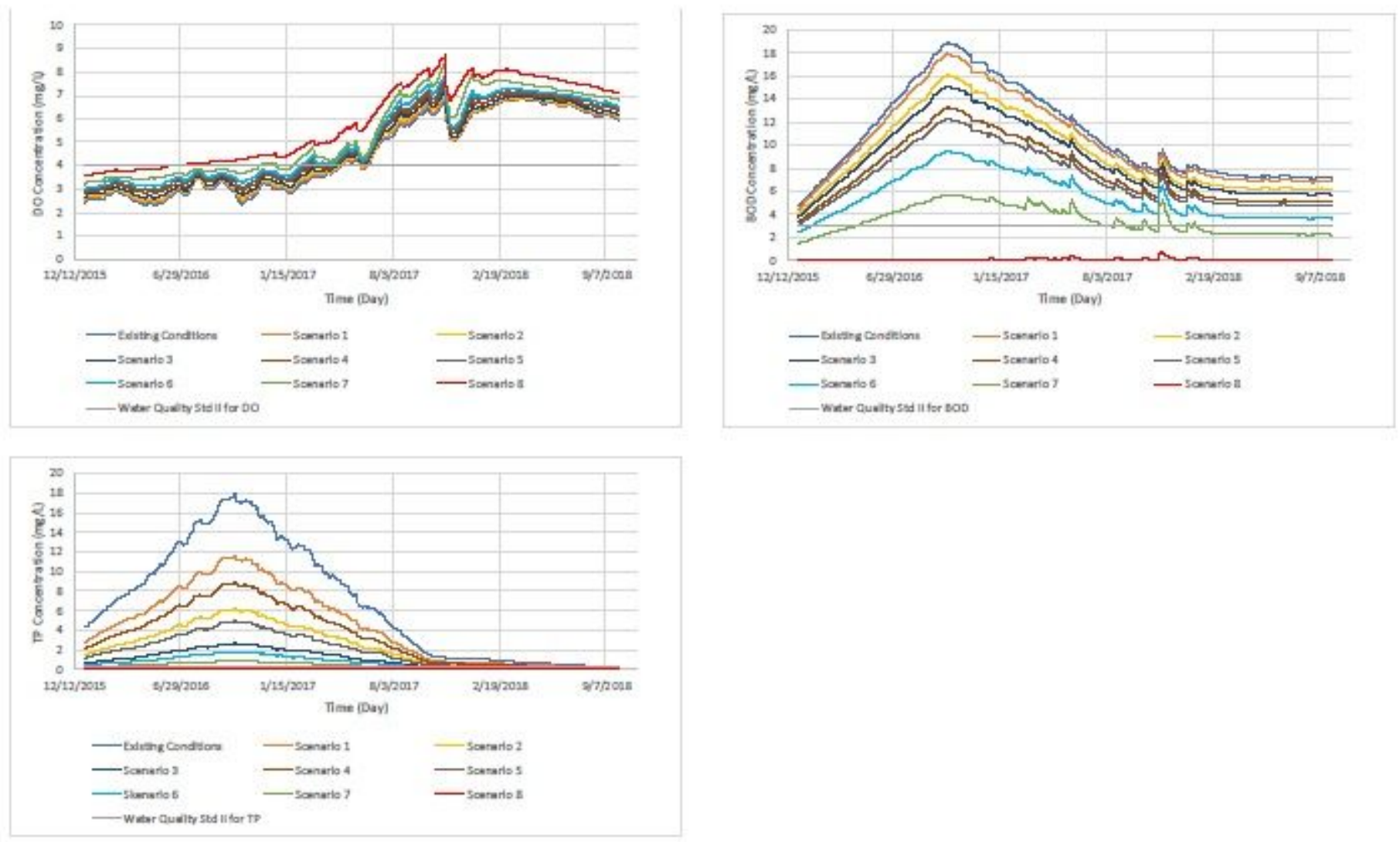

\section{Figure 25}

Simulation results for Point 8 